\title{
WHY SOME STATES COMPLY LESS THAN OTHERS
}

This chapter tackles the first puzzle of the book: Why do long-standing member states comply less than states that joined the EU more recently? Enforcement, management, and legitimacy approaches address member state noncompliance. Yet the question is not only—and increasingly less so-why states (do not) comply but why some comply less than others. Enforcement has to come to terms with France and Italy wielding power in the EU similar to that of Germany and the UK but being much less compliant. The UK and Germany are equally resourceful but differ in their compliance performance, which is hard to explain for management. Neither enforcement nor management can account for why twelve of the thirteen countries that joined the EU in the 2000s and whose power and capacity are equally limited comply on average better than the old member states of the EU-15. This is also a problem for legitimacy, since the new member states have had less time to internalize EU norms and rules. Nor can legitimacy explain why member states, such as the UK and Sweden, where public support for the EU is low, are among the top compliers.

The PCP model solves these puzzles by combining power, capacity, and politicization. Member states like Italy and France, which have the power to resist compliance with costly EU laws and limited capacity to cope with the costs, are the worst compliers. Germany and the UK have similar power but more capacity, as a result of which they are better compliers. Unlike France and Italy, Greece and Portugal have no power to resist compliance, but their capacity is equally limited. Politicization helps explain why Belgium, Ireland, and Luxembourg comply less than other small countries, such as Sweden, Finland, and Denmark, with similarly 
high capacity. Their Europhile publics render politicization less likely, so governments cannot claim their hands are tied and negotiate for less costly EU laws in the Council. This also accounts for the different noncompliance behavior of Germany and the UK, which do not differ in their power and capacity either. The UK was the member state with by far the highest level of Euroscepticism, allowing it to either opt out of costly EU law or to reduce the costs by bringing EU law closer to its policy preferences. Politicization is the answer to why Eurosceptic member states comply better than member states with strong public support for the EU.

Noncompliance is not a problem of the EU's southern member states. Nor is it an eastern problem. On the contrary, the ten CEE countries that joined the EU in the first decade of the twenty-first century have performed better than most of the long-standing member states. The PCP model explains this puzzle by the limited power of the newcomers to resist costly EU laws and the specific capacity they built up during the accession process for coping with compliance costs. To evaluate this argument empirically, the second part of the chapter reviews the state of the art on member state noncompliance with EU law for conceptualizations and operationalizations to identify power, capacity, and politicization. A statistical model, which tests the observable implications of power, capacity, and politicization for their causal relevance, reduces the number to five specifications of those three concepts: voting power, bureaucratic quality, public opposition to the EU, political constraints, and parliamentary scrutiny. The second part draws on these findings to refine the PCP model with regard to variation in member state noncompliance. I use descriptive data and narrative evidence to show how power, capacity, and politicization work together in affecting the noncompliance behavior of the member states.

\section{From a Southern to an Eastern Problem?}

At first sight, member state noncompliance in the EU may suggest a North-South divide (figure 3.1; see also figure 1.4).

The variation revealed by the distribution of infringement data largely conforms to findings in the broader literature. There is an uncontested group of compliance leaders, which include the three Nordic countries, the UK, and the Netherlands. ${ }^{1}$ There is equal agreement on the laggards comprising Greece, Portugal, Italy, Belgium, and France. This leaves Germany, Austria, Spain, Luxembourg, and Ireland for the inconspicuous, the latter two of which are sometimes placed in the laggards group (Bergman 2000; Falkner, Treib, and Holzleitner 2008). The contrast between the exemplary performance of the Nordic countries, on the one hand, and the poor record of Italy, Greece, and Portugal, on the other, 


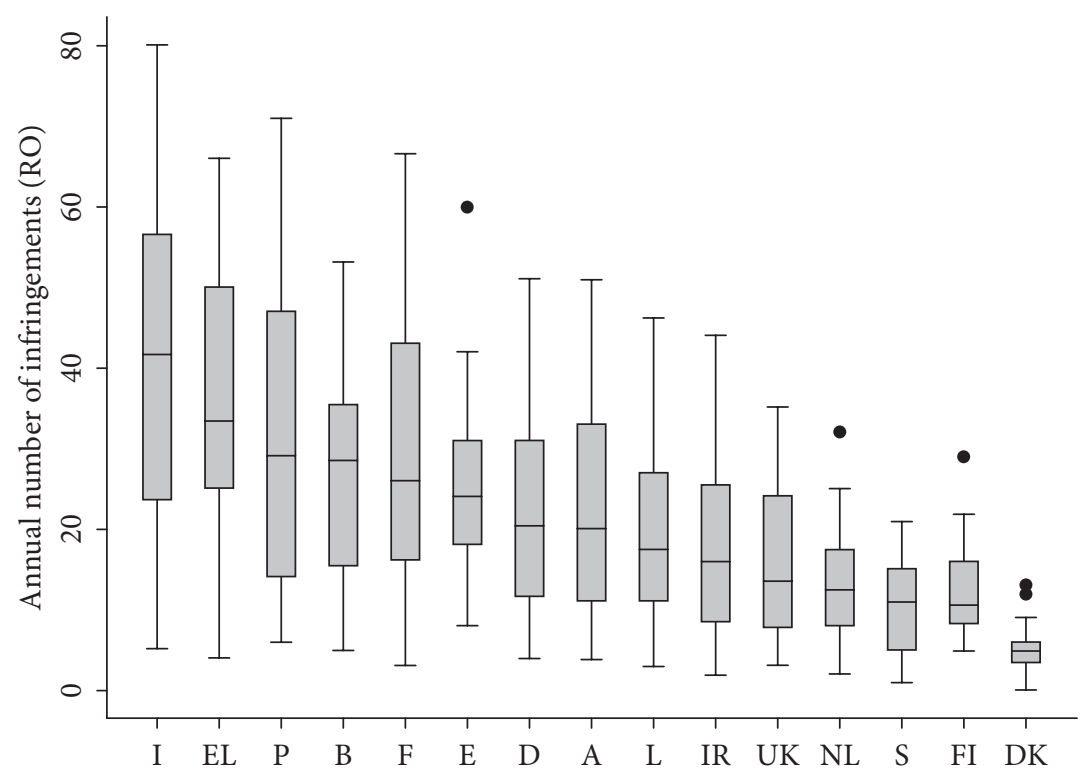

FIGURE 3.1. Annual average of reasoned opinions by member states, EU-15, 1978-2017

Source: Own compilation, with data from the Berlin Infringement Database. The graph shows the statistical distribution of the annual number of infringements (1978-2017) per member state. For acceding member states, the first year of membership was omitted.

gave rise to arguments that noncompliance in the EU was a "southern problem" (La Spina and Sciortino 1993; Pridham and Cini 1994; Falkner et al. 2005). Southern European member states allegedly share some features of their political and administrative systems that render them unable to effectively implement EU law. First, these countries appear to lack the capacity to effectively implement European policies. Southern administrations often do not possess sufficient technical expertise, staff, and infrastructure to effectively apply and enforce EU legislation (Pridham 1994, 89-90; La Spina and Sciortino 1993, 224). Moreover, policy making in these countries is reactive in style, which often contradicts the proactive approach embodied in EU policies (Aguilar Fernandez 1994; Pridham 1996, 53). Second, horizontal and vertical fragmentation of administrative structures tends to be high. As a result, resources required for effective implementation are scarce and widely dispersed among a multitude of public authorities and bureaucracies, which are too inefficient to pool them in the implementation process. Third, societal actors are found to be weak as a result of late modernization and democratization. Authoritarian legacies have undermined the organizational capacities of civil society. Lower levels of socioeconomic development 
have prevented the emergence of post-material values, a precondition for strong social movements, which could generate domestic compliance costs (Eder and Kousis 2001). Finally, some authors have implied that the problems of the southern member states in complying with EU law can be understood as the result of a fundamental clash of political cultures. Southern European countries have political systems traditionally dominated by party patronage and bureaucratic clientelism (Sotiropoulos 2004). Political parties offer voters jobs in the public sector, sidestepping regular recruitment procedures. Likewise, after each government turnover, top administrators in the civil service are replaced by appointees of the new governing party. Patronage and clientelism undermine bureaucratic efficiency. They result in an overproduction of laws and decrees that frequently lack implementation and enforcement, further undermining the respect for public authority. This Mediterranean political culture contradicts the Northern European political culture, which is built on corporate forms of social organization and which also forms the base of many EU laws (La Spina and Sciortino 1993; Aguilar Fernandez 1994; Pridham and Cini 1994; Falkner et al. 2005).

There can be no doubt that the Southern European member states have considerable problems in complying with EU law. But it is doubtful whether these problems are part of a homogeneous phenomenon or a "disease" dubbed the "Mediterranean syndrome" (La Spina and Sciortino 1993). First, the Southern European countries are quite diverse with respect to their political and administrative institutions (cf. Börzel 2003a). Second, if there exists such a thing as a "southern problem" or a "Mediterranean syndrome," why do we find considerable variation in noncompliance among and within the Southern European and Northern European member states? France may still be considered a Southern European country; Belgium is certainly not. At the same time, Spain performs closer to Luxembourg, Ireland, Austria, and Germany, which are firmly based in the Northern European camp. Interestingly, no study assigns Spain to the laggards group led by Italy and Greece (Haverland, Steunenberg, and van Waarden 2011; Haverland and Romeijn 2007; Hartlapp and Leiber 2010; König and Luetgert 2009; Falkner, Hartlapp, and Treib 2007; Kaeding 2006; Börzel 2000b). Italy, finally, violates EU law significantly more than Greece and Portugal. In short, the South of Europe has a problem with noncompliance, but noncompliance is not a southern problem.

Eastern enlargement has fueled arguments about a geographic patterning of noncompliance in the EU. Similar to the Southern European laggards, the Central and Eastern European (CEE) countries were suspected of showing symptoms of the "Mediterranean syndrome": inefficient administrations ridden by patronage and corruption, legacies of authoritarianism, weakly organized societal interests, and low levels of socioeconomic development. The problems of weak states and 
weak societies were inherent to state socialism (Sissenich 2005; Börzel 2009b; Crawford and Lijphart 1997; Cirtautas and Schimmelfennig 2010). They met in Central and Eastern Europe with the formidable challenges of mastering a triple transition toward democracy, market economy, and (new) nations (Offe 1991; Elster, Offe, and Preuss 1998; Kuzio 2001), on the one hand, and the accession to the EU, on the other (Mungiu-Pippidi 2014; Bruszt and Vukov 2018). EU membership was to support and lock in the political, economic, and social transition processes (Linden 2002; Jacoby 2004; Vachudova 2005; Grabbe 2006; Epstein 2008). At the same time, the implementation of the acquis communautaire with its thousands of laws put further strains on the scarce administrative and political capacities of the candidate countries (Börzel 2009a). EU accession conditionality and assistance was to tackle the problem of high costs and low capacities (Schimmelfennig, Engert, and Knobel 2003; Schimmelfennig and Sedelmeier 2004; Vachudova 2005; Börzel 2009a; Bruszt and McDermott 2009; Börzel and Sedelmeier 2017; Bruszt and Langbein 2017). With membership, however, the powerful leverage of accession conditionality was gone (Schimmelfennig and Sedelmeier 2005, 226; Steunenberg and Dimitrova 2007, 1; Sedelmeier 2008, 809-810; Börzel and Schimmelfennig 2017). Moreover, despite profound politi$\mathrm{cal}$ and economic reforms, clientelism and corruption largely survived the collapse of state socialism. Where one party used to capture the state, several political parties compete now for the extraction of state resources (Houghton 2014). "Competitive particularism" (Mungiu-Pippidi 2006) and state capture reigns in post-communist countries, though in different forms and to different degrees (Gryzmala-Busse 2007; Kopecky and Scherlis 2008; Batory 2012; Innes 2014). Similar to the situation in the Southern European member states, the combination of high costs, weak incentives, and limited capacity of both state and society have raised concerns about (sustained) compliance with EU law (Falkner, Treib, and Holzleitner 2008; Dimitrova 2010).

It is still difficult to assess the compliance performance of the new member states (cf. Epstein and Sedelmeier 2009; Schimmelfennig and Trauner 2010). As in the case of Southern European member states, the Commission granted the CEE countries a period of grace before it started to systematically open infringement proceedings (Tosun 2011). Quantitative studies do not find a particular compliance problem in the East of Europe (Sedelmeier 2006, 2008, 2012; Toshkov 2008; Dimitrova and Toshkov 2007; Steunenberg and Toshkov 2009; Zhelyazkova et al. 2014; Zhelyazkova and Yordanova 2015; Zhelyazkova, Kaya, and Schrama 2016, 2017; Börzel and Sedelmeier 2017). While the number of infringement proceedings briefly peaked in 2004, it kept declining ever since. As chapter 4 will show in more detail, eastern enlargement has had no discernible effect on the reported infringements of EU law. This is also the case for preliminary rulings. The annual 
average number of preliminary rulings for the new member states is among the lowest.

The Commission has been full of praise for the newcomers, stating that "the new Member States ... perform better in transposing Internal Market directives on time than the EU-15 Member States despite having had to absorb the whole acquis in a short time frame" (European Commission 2005, 5). It calls the new member states "the champions in reducing transposition deficits" (ibid., 12). They transpose directives as fast, some even faster, than the old member states. They also tend to settle their infringement procedures more swiftly, too (Dimitrova and Toshkov 2007; Sedelmeier 2008; Toshkov 2007a, 2008; Steunenberg and Toshkov 2009).

Case study research on the new member states, however, has revealed serious violations of EU norms and rules in their practical application and enforcement. Some have taken this as an indication that the EU's southern problem has turned into an eastern problem based on the same symptoms of captured states and weak civil societies (Falkner, Treib, and Holzleitner 2008; Spendzharova and Vachudova 2012; Trauner 2009; Kriszan 2009; Buzogány 2009). The diverging findings are not necessarily contradictory or produced by different data and methods. Rather, they may point to a decoupling between reasonable legal compliance, on the one hand, and poor practical application and enforcement on the ground, on the other (Falkner, Treib, and Holzleitner 2008; Batory 2012; Cirtautas and Schimmelfennig 2010; Sedelmeier 2012; Avdeyeva 2010; Dimitrova 2010; Dimitrova and Steunenberg 2013; Trauner 2009; Slapin 2015; Zhelyazkova, Kaya, and Schrama 2016). In the "world of dead letters" (Falkner, Treib, and Holzleitner 2008), EU law gets swiftly incorporated into national law but is not put into action. Such decoupling was already observed during the accession process of the CEE countries, where "many rules have been only formally transposed into national legislation but are not fully or reliably implemented" (Schimmelfennig and Sedelmeier 2005, 226; Hughes, Sasse, and Gordon 2004; Jacoby 2004; Sissenich 2005; Goetz 2005; Leiber 2007). Post-accession studies have even found some evidence for reversing compliance with EU law. Such backtracking, however, significantly varies both across countries and policy sectors and appears to be limited by the extent to which the new member states are dependent on EU aid and trade, as well as by the mobilization of societal interests (Pridham 2008; Blauberger 2009a; Levitz and Pop-Eleches 2009, 2010; Hollyer 2010; Sedelmeier 2012; Dimitrova and Buzogány 2014).

Even if the new member states face problems in practically applying and enforcing EU law, their compliance behavior cannot be simply reduced to being transposition leaders but application laggards, which would put them ultimately into the same camp as Greece, Italy, Portugal, Belgium, or France. First, the 
formal compliance records of the new members vary too much for decoupling to be a uniform phenomenon (figure 3.2). ${ }^{2}$

More substantively, case studies have so far failed to establish "dead letters" as a pervasive problem for all CEE members. Evidence for this claim relies primarily on the study of social policy directives in the new members by Falkner, Treib, and Holzleitner (2008). Yet the social policy directives examined, and gender equality at the workplace in particular, are generally highly prone to decoupling in old and new members alike. To some extent, decoupling might be characteristic of issue-area-specific difficulties of enforcement, even if the relevant domestic enforcement bodies for workplace regulation are particularly weak in postcommunist new members (Falkner 2010). Other case studies have found hardly any evidence of an "eastern world of dead letters." Toshkov's detailed analyses of three policy areas-electronic communications, consumer protection, and animal welfare-suggest that shortcomings with practical implementation and application of EU law in the eastern member states are not "of a greater scale and different nature in CEE, and there is no evidence that the EU rules have been mindlessly copied and forgotten" (Toshkov 2012, 108). The comparative analysis by Zhelyazkova, Kaya, and Schrama (2017) that draws on in-depth conformity

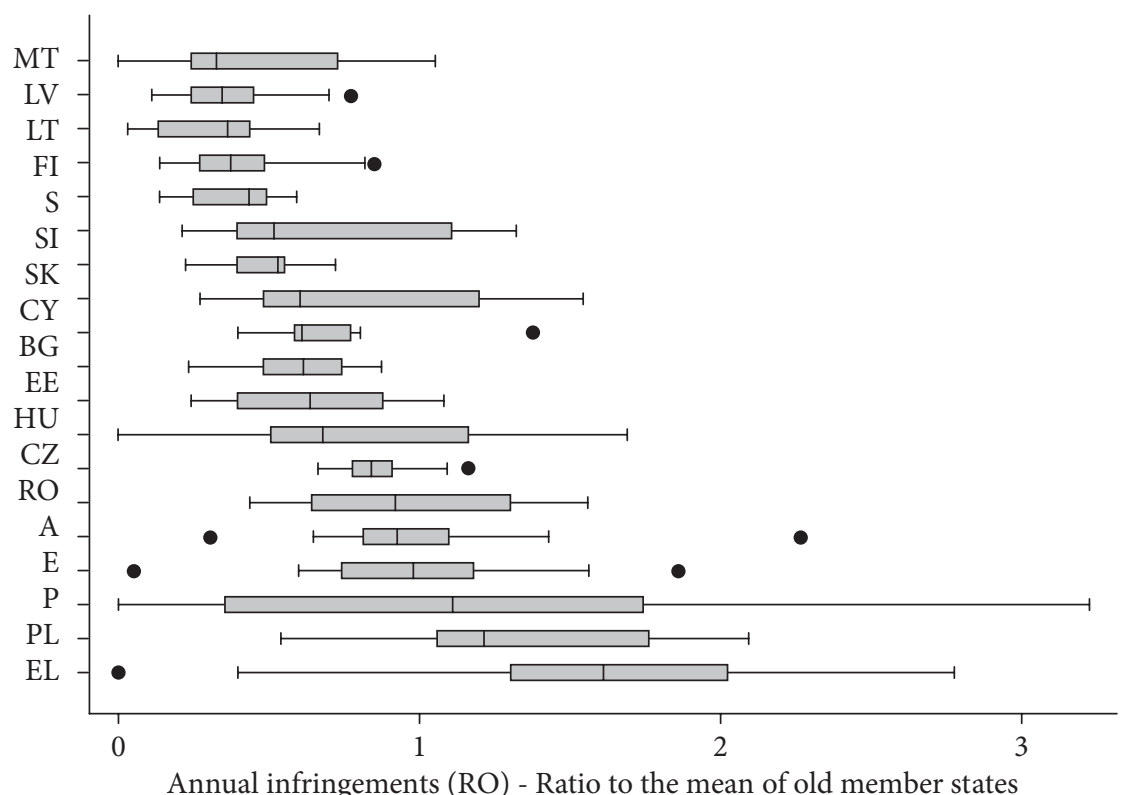

FIGURE 3.2. Annual reasoned opinions of new members compared to old member states Source: Own compilation, with data from the Berlin Infringement Database. 
studies of practical application of twenty-four directives across four policy areas (Internal Market, Environment, Social Policy, and Justice and Home Affairs) also suggests that decoupling is not more prominent in the new members than in the EU-15-with the exception of Social Policy (Zhelyazkova, Kaya, and Schrama 2016, 2017). Of course, such counterevidence may be prone to criticism, too, for instance for relying too much on evaluation reports prepared by consultancies contracted in many cases by the Commission, as a result of which their quality may be contested (see Mastenbroek, van Voorst, and Meuwese 2015). Moreover, many studies draw conclusions from a limited number of policy areas (Falkner, Treib, and Holzleitner 2008). Clearly, there is evidence for some serious compliance problems regarding the practical application of EU law in post-communist member states, which merit further investigation. It might be too early to dismiss decoupling completely as a possible explanation for the good record of eastern new members. However, it appears equally questionable that decoupling is a pervasive phenomenon that explains away their performance.

Second, similar to the Southern Europeans, the CEE newcomers do not form a homogeneous group. While thirteen years (ten years for Romania and Bulgaria) of infringement data may not allow for a systematic comparison yet, existing research has identified Bulgaria and Romania as notorious compliance laggards. They do not only fail to fight corruption and transborder crime, for which the EU installed some post-accession conditionality (Gateva 2010; Pridham 2007; Spendzharova and Vachudova 2012). They do not abide with EU law in the other areas, either (Noutcheva and Bechev 2008; Trauner 2009; Hille and Knill 2006; Knill and Tosun 2009). The three Baltic countries, Slovenia, and Slovakia perform considerably and consistently better, whereas Hungary, Poland, the Czech Republic, Malta, and Cyprus range in the middle (Hille and Knill 2006; Knill and Tosun 2009; Steunenberg and Toshkov 2009). Infringement data confirms variation but finds different patterns (Börzel and Sedelmeier 2017). Lithuania is as good a complier as Denmark, while Bulgaria and Romania are close to Hungary, Latvia, Slovenia, Slovakia, Sweden, and Finland. The Czech Republic and Poland are closing in with Germany and Spain (see figure 1.3 in chapter 1).

The lack of support for an East-West divide does not come as a surprise for the PCP model. While not necessarily denying the effect of socialist legacies on noncompliance in Central and Eastern Europe, "these legacies do not carry equal weight across the region" (Cirtautas and Schimmelfennig 2010, 428; cf. Seleny 2007; cf. Toshkov 2007b, 2008; Sedelmeier 2009; Schwellnus 2009; Börzel and Sedelmeier 2017).

The following sections review research on noncompliance with EU law for conceptualizations and operationalizations of power, capacity, and politicization. 
The aim is to limit the number of variables included in the PCP model to those the literature has found to be empirically relevant.

\section{Explaining Member State Noncompliance Shaping Compliance Costs}

The PCP model expects noncompliance to be the more likely the more limited the ability of member states is to shape EU law according to their policy preferences and thus reduce compliance costs in the taking of EU law.

\section{POLITICAL AND ECONOMIC POWER}

The power of member states to shape policy outcomes at the EU level plays an important role in the compliance literature. The focus has been on the number of votes that member states hold in the Council of the EU, as well as their budget contributions and trade shares. Many studies find that more voting, budgetary, and economic power leads to more rather than less noncompliance (Mbaye 2001; Giuliani 2003; Sverdrup 2004; Perkins and Neumayer 2007; Jensen 2007; Börzel et al. 2010). This indicates that power may be relevant to resist compliance costs or deter enforcement authorities at the taking stage rather than to reduce costs at the shaping stage.

The PCP model assumes that EU institutions mitigate the power of member states (see also Panke 2010b). Findings on whether QMV increases the probability of noncompliance because majority rule deprives individual member states of their power to veto proposals that go against their preferences are inconclusive (Mbaye 2001; Haverland and Romeijn 2007; König and Luetgert 2009). This may be at least partly due to voting rules being policy or issue specific. QMV does not systematically vary across countries (Börzel and Knoll 2013). Whether member states that voted against an EU law or abstained are less likely to comply is not clear either. Studies have found that negative votes or abstentions in the Council yield positive, negative, or no significant effect on noncompliance (Linos 2007; Toshkov 2010, 34; Angelova, Dannwolf, and König 2012, 1278).

\section{CAPACITY AND POLITICIZATION}

Compliance studies show that capacity-related factors are relevant in the taking rather than shaping of EU law and its costs. The same is true for politicization (see below). Research has so far neglected whether and to what extent the resource endowment of member states, their bureaucratic efficiency, and their domestic autonomy enable them to obtain more favorable policy outcomes thereby affecting their noncompliance behavior. 


\section{POLICY MISFIT AND EU BENEFITS (CONTROLS)}

Several studies have developed concepts and indicators to capture the costs of noncompliance directly rather than as the effect of the shaping power of states. Costs are the result of the degree of misfit between EU and domestic law. The higher the policy misfit, the higher the compliance costs, and the more likely is noncompliance (Duina 1997; Duina and Blythe 1999; Knill 1998; Thomson 2007; Thomson, Torenvield, and Arregui 2007; König and Mäder 2013; König and Luetgert 2009). Policy misfit is hard to quantify. It is also difficult to see why it should vary systematically among member states, unless their ability to shape EU law according to their preferences is brought in. Moreover, empirical research has shown that governments comply with even costly EU laws if these laws correspond to their policy preferences and vice versa (Ademmer and Börzel 2013; Börzel and Pamuk 2012; Sprungk 2011, 2013; König and Mäder 2014b). Finally, member states weigh the costs of compliance against the benefits. Scholars have argued that member states should be less likely to violate costly EU laws if compliance yields general benefits because a large share of their trade goes into the Internal Market or they are net recipients of EU funds (Mbaye 2001; Perkins and Neumayer 2007; König and Luetgert 2009; Knill and Tosun 2009). Not being directly part of the PCP model, the empirical analysis will include policy misfit and EU benefits as control variables to the extent that data is available.

\section{Taking Compliance Costs}

According to the PCP model, member states are the more likely to violate EU law the less able they are to resist compliance costs, to deter enforcement authorities, and to cope with compliance costs domestically.

\section{POWER: RECALCITRANCE AND DETERRENCE}

The robust support in the literature for a positive relationship between the voting power of member states and the size of their economy and population, on the one hand, and their violations of EU law, on the other (see above), corroborates the expectation of the PCP model that power primarily enables member states to be recalcitrant and resist compliance (see Börzel et al. 2010; Börzel, Hofmann, and Panke 2012). They could also use their votes, budget contributions, or trade shares to deter the Commission and the ECJ from enforcing EU law. In this case, we would expect their noncompliance performance to be lower, because they should face fewer infringements. I have argued in chapter 1 that there is no deterrence effect. The empirical analysis should lend further support for my argument that member state power does not bias infringement data. 


\section{CAPACITY: RESOURCES AND EFFICIENCY}

When it comes to the capacity to cope with compliance costs, EU scholars have found that economic wealth, fiscal revenue, and government expenditure are not associated with noncompliance (Mbaye 2001; Hille and Knill 2006; Börzel et al. 2010). Rather than state resources, they emphasize bureaucratic efficiency-the ability of a government to apply its resources to the effective implementation of EU law (Siedentopf and Ziller 1988; Falkner et al. 2005; but see Ciavarini Azzi 1988; Pridham and Cini 1994; Dimitrakopoulos 2001). Both quantitative and qualitative research have generated strong evidence that bureaucratic inefficiency is a crucial problem for noncompliance. Even if a state has sufficient resources and the autonomy to deploy them, its administration may still have difficulties in pooling and coordinating them, particularly if the required resources are dispersed among various public agencies (e.g., ministries) and levels of government (Mbaye 2001; Linos 2007; Egeberg 1999; Mastenbroek 2003; Börzel 2003a; Haverland and Romeijn 2007; Steunenberg 2006; Steunenberg and Toshkov 2009; Zhelyazkova, Kaya, and Schrama 2016). Member states with Weberian-type bureaucracies are found to be better compliers because of the competence and independence of civil servants (Mbaye 2001; Bursens 2002; Berglund, Grange, and van Waarden 2006; Börzel et al. 2010; Hille and Knill 2006; Toshkov 2008). In a similar vein, a high level of corruption undermines a member state's capacity to comply with EU law, since the enforcement of (costly) EU legislation is likely to be determined by political favoritism (Mbaye 2001; Linos 2007; Kaeding 2006).

Eastern enlargement has corroborated the importance of bureaucratic efficiency for compliance with EU law. Coordination problems undermine a state's capacity, superseding any other factor in accounting for noncompliance in the CEE countries, before (Zubek 2005; Hille and Knill 2006; Dimitrova and Toshkov 2007) as well as after their accession to the EU (Knill and Tosun 2009; Dimitrova and Toshkov 2009; Falkner 2010; Zubek 2011; Zubek and Goetz 2010).

Italy and France are two cases where the two components of capacity diverge. They are among the largest economies of Europe and command more resources than Greece, which belongs to the poorest member states. Yet these three member states are equally plagued by relatively inefficient bureaucracies, although France still fares better than Italy (Nachmias and Rosenbloom 1978, 181; Auer, Demmke, and Polet 1996; Charron, Dijkstra, and Lapuente 2010).

\section{POLITICIZATION: VETO PLAYERS AND EUROSCEPTICISM}

Compliance studies find that veto players are a major source of noncompliance. Next to the number of institutional veto players, the degree of territorial decentralization (regionalism/federalism) has a positive effect on noncompliance 
(Dimitrova and Steunenberg 2000; Mbaye 2001; Linos 2007; Thomson 2007; Haverland and Romeijn 2007; Jensen 2007; Kaeding 2008; König and Luetgert 2009; Borghetto and Franchino 2010; Thomann 2015). So do the number of national ministries involved (Mastenbroek 2003; Steunenberg 2006; Haverland and Romeijn 2007; Steunenberg and Toshkov 2009), the number of parties in government (Toshkov 2007b, 2008; König and Luetgert 2009; Luetgert and Dannwolf 2009), and interest-group pluralism (Giuliani 2003; König and Luetgert 2009; Jensen 2007).

Findings on corporatism, by contrast, are inconclusive, which might be related to its theoretically ambivalent effect of social partners constituting (in some sectors) powerful veto players, on the one hand (König and Luetgert 2009; Kaeding 2006), and helping to neutralize veto players through negotiations, on the other (Héritier 2001; Lampinen and Uusikylä 1998; Mbaye 2001; Börzel and Risse 2003; Hille and Knill 2006; Thomson 2007). The involvement of national parliaments and their scrutiny of EU laws in decision making have not produced robust results either. While some treat parliaments as veto players (Steunenberg 2006; König and Luetgert 2009), others argue their involvement fosters political acceptance (Krislov, Ehlermann, and Weiler 1986; Bergman 2000) or find that the effect of parliamentary involvement varies depending on the outcome variable (Linos 2007).

Euroscepticism features at best indirectly in compliance research. It is the opposite of EU support. Legitimacy approaches argue that member states are less likely to violate EU law the more it is accepted as part of the law of the land either by the national government or by the broader public. The first may depend on the affinity of political elites or government parties to the EU as the rule-setting institution (Linos 2007; Hille and Knill 2006; König and Luetgert 2009); the latter is shaped by citizens' support for European integration and their respect for the rule of law, and the length of membership (Gibson and Caldeira 1995; Lampinen and Uusikylä 1998; Mbaye 2001; Toshkov 2007b; Slapin 2015).

The literature has found little support for the effect of ideological positions of ruling parties and their EU affinity on noncompliance (Jensen 2007; Linos 2007; Toshkov 2007a, 2007b; Hille and Knill 2006; but see Toshkov 2008; Sedelmeier 2009). Length of membership, support for the EU, and respect for rule of law have yielded no consistent results (see above). Public acceptance of EU membership is either irrelevant or leads to more, not less, noncompliance. It has been argued that support is picked up by capacity because citizens hope that the EU will compensate for the incapacity of their state to provide public goods and services (Sánchez-Cuenca 2000; Toshkov 2007a). The poor results for rule of law, finally, have been at least partly attributed to measurement problems (Börzel et al. 2010; Berglund, Grange, and van Waarden 2006). Next to the lack of good 
data, culture is an institutional variable that shows very little longitudinal and no sectoral or policy variation. Moreover, the Nordic countries, whose populations show high levels of respect for the rule of law (Sverdrup 2004; Beach 2005; Falkner et al. 2005), also feature high levels of capacity (Lampinen and Uusikylä 1998; Bergman 2000; Toshkov 2007a). Indicators for bureaucratic efficiency, such as bureaucratic quality or corruption, highly correlate with rule of law.

The PCP model accounts for the mixed findings of the effects of politicization on noncompliance. Veto players and Euroscepticism reduce the autonomy of a state vis-à-vis its society. At the taking stage, domestic actors that are aware of and care about compliance costs increase the likelihood of noncompliance because they are likely to block or delay the implementation of EU law. At the shaping stage, veto players and opposition to the EU increase the ability of member states to limit compliance costs because they can tie their government's hands, which should reduce the chances of noncompliance. The next section puts these conflicting expectations to an empirical test.

\section{Evaluating Power, Capacity, and Politicization}

To limit the possibilities of model specification, I confine myself to those variables that have found at least some support in the literature in explaining country variation in noncompliance. Moreover, the variables need to yield empirically observable implications that can be measured by meaningful time series data. Some, such as policy misfit or salience, are rule or policy specific and will be considered in chapters 4 and 5. For others, such as the respect for the rule of law, there is simply no data available that covers all EU member states over a period of thirty years. ${ }^{3}$ This may explain why these factors do not fare well in quantitative studies. In other cases, including EU affinity of the ruling party or party ideology, neither case studies nor statistical analyses of more limited scope offer sufficient support to merit efforts to compile new and better data. Finally, veto players, and the professionalism of the public administration, do not show much variation across time. I have, therefore, opted for alternative variables as proxies for capacity and politicization that have not figured prominently in the literature so far.

\section{Data and Method}

For evaluating the effects of power, capacity, and politicization variables on member state noncompliance, I can use the absolute numbers of reasoned opinions sent, because the amount of EU legislation in a given year that member states in that year have to comply with is the same. Since data on some independent 
variables is only available till 2012, the initial analysis focuses on the EU-15 (see chapter 1). Data on two of the independent variables is only available for directives, which lie at the heart of EU noncompliance (see chapter 4). Nevertheless, I decided to include all infringements in the analysis. The results of my analyses remain the same irrespective of whether I take the official infringements of regulations and directives or directives only.

The dependent variable is the annual number of reasoned opinions based on noncompliance with EU legal acts that a member state receives. A closer look at the distribution of this count variable reveals that the variance is greater than the mean. This overdispersion in the data violates a central assumption of the Poisson regression. A negative binomial regression is used in the first model to avoid inefficient estimates. Summary statistics are listed in table A1.1. The Hausman test is highly significant regarding the unit-specific differences between years. The level of noncompliance varies systematically between years. To control for the time effects, I calculate a negative binomial count model with year fixed effects. Country fixed effects are not included, since the Hausman test is insignificant for them. Moreover, country fixed effects would eliminate precisely the between-country variation in which I am interested.

The operationalization of the independent variables is more challenging, particularly when it comes to the factors that are relevant at the shaping stage (for a summary see table A3.1). The power to shape compliance costs or resist them can be operationalized with two measures. They account for the two different aspects of power-voting power and economic power. Member states that have both cannot be ignored by others in EU decision making, even if they may have lost credibility by not abiding with previously agreed-upon rules (Perkins and Neumayer 2007; Jensen 2007; Börzel et al. 2010). In addition, their economic power renders them less sensitive to sanctioning costs in the form of financial penalties or the withholding of EU subsidies. Voting power can be captured by the proportion of times when a member state is pivotal (and can thus turn a losing into a winning coalition) under QMV in the Council of Ministers (Shapley Shubik Index [SSI], Shapley and Shubik 1954; Rodden 2002). GDP is a proxy for economic power (Keohane 1989; Martin 1992; Moravcsik 1998; Steinberg 2002). Population is relevant but heavily influences both power indicators, GDP and the SSI. The number of votes a member state has in the Council of Ministers is based on the size of its population, even though the conversion factor for population to relative voting power has changed over time owing to the successive enlargements of the EU. The Lisbon Treaty introduced the double majority, requiring 55 percent of member states to be in favor of a proposal representing 65 percent of the total EU population. This new rule has applied since 2014, which is outside the time covered by this analysis. Not surprisingly, GDP and SSI voting 
power significantly correlate. There is also a high, negative correlation between GDP and net recipient, which reflects the design of EU redistributive policies (see chapter 5). My previous research has shown that the size of the economy does not matter when it comes to infringements on EU law (Börzel et al. 2010). Accordingly, GDP is dropped from the model.

Capacity is equally relevant to the shaping and taking of EU law and its costs. Unlike power and politicization, its effect on noncompliance does not differ depending on the stage of the compliance game. To test for the influence of capacity on the distribution of noncompliance, I include two indicators that are prominent in the literature. GDP per capita is a general measure for the resources on which a state can draw to ensure compliance (Brautigam 1996). The data comes from the World Development Indicators of the World Bank. Some studies use fiscal revenue (Mbaye 2001; Hille and Knill 2006), yet it highly correlates with GDP, SSI, and net recipient (see table A2.2).

Whether a state has the capacity to mobilize its resources is captured by bureaucratic efficiency. The operationalization is not easy, mostly because of the lack of time series data. For instance, Auer and her colleagues developed a bureaucratic quality index consisting of three components: performance-related pay for civil servants, lack of permanent tenure, and public advertising of open positions (Auer, Demmke, and Polet 1996; Mbaye 2001; Berglund, Grange, and van Waarden 2006; Hille and Knill 2006; Toshkov 2008). However, they cover only the year of 1993. The World Development Indicators of the World Bank, such as government effectiveness or regulatory quality, are not available for the entire time period analyzed either. The International Country Risk Guide (ICRG) provides some rare time series data for bureaucratic quality. It measures the ability and expertise of states to govern without drastic changes in policy or interruptions in government services, the extent to which their bureaucracy is autonomous from political pressure and has an established mechanism for recruitment and training, and also evaluates policy formulation and day-to-day administrative functions. The advantage of ICRG bureaucratic quality over alternative measurements is not only its availability but also its validity. It highly correlates with the World Development Indicators of the World Bank for government efficiency and regulatory quality, as well as with different corruption indicators, which are frequently used as an indicator for bureaucratic quality (Mbaye 2001; Linos 2007; Zhelyazkova, Kaya, and Schrama 2016).

Politicization is a function of domestic veto players that have the institutional power to block domestic change required to comply with EU law and the likelihood that they actually invoke their power to oppose compliance costs. At the shaping stage, politicization makes noncompliance less likely, since it enhances the ability of governments to negotiate for less costly EU laws. At the taking stage, 
in contrast, domestic opposition increases the risks of noncompliance. The most prominent indicator used in the literature is the number of veto players in the political system of a member state (Tsebelis 2002; Immergut 1998). However, even if the number of the institutional and partisan veto players remains constant over time, the interests of these actors regarding (non)compliance may change. This is also the case for corporatism and interest pluralism, which may explain why they do not show any consistent results. Therefore, I use two alternative indicators. First, the political constraints index (POLCON) provides an alternative veto player index that accounts for the interests of veto players in such a way that interdependences between veto players and the respective political system are taken into consideration (Henisz 2002). It is based on a simple spatial model of political interaction among government branches (horizontal separation of power), measuring the number of independent branches with veto power and the distribution of political preferences across these branches. They can be interpreted as a measure of political constraints that either preclude arbitrary changes of existing policies or produce gridlock and so undermine the ability of the government to change policies when such change is needed. Second, next to the horizontal separation of power, I also cover the vertical dimension in terms of the degree of territorial decentralization using the regional authority index (Marks, Hooghe, and Schakel 2010; Hooghe et al. 2016). In federal states, subnational authorities are true institutional veto players in the legal implementation process through their representation in the second chamber of the national legislature. They are also in charge of practical application and enforcement. So are provinces, counties, and municipalities in regionalized and decentralized states (Mbaye 2001; Linos 2007; Thomson 2007; König and Luetgert 2009; Jensen 2007; Kaeding 2008; Borghetto and Franchino 2010; Thomann 2015; Tatham 2018).

Two alternative indicators of political constraints are discussed in the literature: the executive control of the parliamentary agenda measured by the extent to which the government can successfully initiate drafts and rely on stable majorities in the legislative branch (Döring 1995; Tsebelis 2002), and the parliamentary oversight of government measured by the material (e.g., number of committees) and ideational resources (e.g., information-processing capacity) relevant for the oversight of the government (Harfst and Schnapp 2003). I do not include these two variables, because of multicollinearity concerns. Moreover, in my previous work, I controlled for both and found robust evidence that they were not significantly correlated with noncompliance (Börzel and Knoll 2013; cf. Knoll 2016). I measure parliamentary scrutiny, though, with the help of data compiled by Thomas König and his collaborators on the average proportion of national transposition measures requiring parliamentary involvement per member state and year (König and Luig 2014; König and Luetgert 2009). 
Data on Euroscepticism or public opposition to the EU are obtained from Eurobarometer surveys. The nonacceptance of European institutions can be quantified by the question that refers to the opposition to the membership of one's own country in the EU. The literature uses the percentage of respondents who think that the membership of their country in the EU is a "good thing" (Gibson and Caldeira 1996; Mbaye 2001; Bergmann 2000; Börzel et al. 2010). Accordingly, I use the percentage of respondents considering European integration a "bad thing" (public opposition).

As for the control variables, two country-specific factors influence the benefits of compliance, which should render violations of EU law less likely. Intra-EU trade is the sum of exports and imports of goods within the EU-15 as share of the GDP in US\$ (Mbaye 2001; Perkins and Neumayer 2007; König and Luetgert 2009; Knill and Tosun 2009). The data is obtained from the OECD International Trade by Commodity. Net recipients receiving more money from the EU than they pay in membership contributions are identified on the basis of the operational budget balance provided by the annual EU budget financial reports and marked by positive values.

Misfit is rule-specific and very hard to quantify for hundreds of legal acts in up to fifteen member states and over a period of more than thirty years. Moreover, studies on member state noncompliance have hardly found any support for its causal relevance. However, there is data on the distance of the outcome of a directive and the party preferences of the ministers in charge of transposition at the time of notified transposition or the transposition deadline (König and Luig 2014). The country-directive specific variable ministerial approval was aggregated by the mean on the country level for each year. While being a rather crude simplification, the data shows some systematic country variation. Lower values represent party preferences in line with the EU legislation in a given year.

To facilitate the interpretation of the results, the independent variables have been rescaled into a two-digit range. All independent variables have been lagged by one year to allow them to take effect. Together with the limits of available data, this leaves us with some missing observations for several independent variables (see table A1.2). Dropping the last two years and the first four years from the analysis does not change the results. I therefore use the 1979-2012 period and fill the missing observations with the values of the previous and, respectively, following year(s). Ministerial approval and national parliamentary scrutiny are available only for directives. For the latter, this is not an issue, since parliamentary scrutiny applies only to the transposition of directives. Ministerial approval can relate to regulations as well. Since the results of the analysis are robust when using infringements of directives only, I decided to include both variables. 


\section{Results and Discussion}

The results show that power, capacity, and politicization have a significant effect on member state noncompliance with EU directives (table 3.1). Some specifications of the three principal components of the PCP model are more relevant than others, though.

\section{POWER}

As expected, power matters at the taking rather than at the shaping stage. The voting power in the Council of Ministers (SSI) has a significant positive effect on noncompliance. France, Italy, and Germany have more Council votes and violate EU law more frequently than member states with low voting power, such as Denmark, Finland, Sweden, or the Netherlands. Recalcitrance, however, has difficulty in accounting for the compliance performance of the UK, on the one hand, and

TABLE 3.1 Power, capacity, and politicization (EU-15, 1979-2012)

\begin{tabular}{|c|c|}
\hline \multicolumn{2}{|l|}{ Power } \\
\hline Voting power (SSI) & $\begin{array}{l}\mathbf{0 . 0 7 1 8}^{\star * *} \\
(0.00724)\end{array}$ \\
\hline \multicolumn{2}{|l|}{ Capacity } \\
\hline GDP per capita & $\begin{array}{c}-0.00395 \\
(0.00267)\end{array}$ \\
\hline Bureaucratic quality (ICRG) & $\begin{array}{l}-\mathbf{0 . 0 4 0 1} 1^{* * *} \\
(0.00464)\end{array}$ \\
\hline \multicolumn{2}{|l|}{ Politicization } \\
\hline Political constraints & $\begin{array}{c}0.00310 \\
(0.00189)\end{array}$ \\
\hline Regional authority & $\begin{array}{l}-\mathbf{0 . 0 0 7 5 5 * * *} \\
(0.00234)\end{array}$ \\
\hline Parliamentary scrutiny & $\begin{array}{l}\mathbf{0 . 0 0 6 4 6 * *} \\
(0.00258)\end{array}$ \\
\hline EU opposition & $\begin{array}{l}-0.0201 * * * \\
(0.00288)\end{array}$ \\
\hline \multicolumn{2}{|l|}{ Controls } \\
\hline Intra-EU trade & $\begin{array}{l}\mathbf{0 . 0 0 7 6 2}^{* * *} \\
(0.00137)\end{array}$ \\
\hline Net recipient & $\begin{array}{c}5.77 \mathrm{e}-06 \\
(7.84 \mathrm{e}-05)\end{array}$ \\
\hline Ministerial approval & $\begin{array}{c}0.000898 \\
(0.00542)\end{array}$ \\
\hline Constant & $\begin{array}{l}3.135 * * * \\
(0.200)\end{array}$ \\
\hline Observations & 440 \\
\hline Number of years & 34 \\
\hline
\end{tabular}


Greece, Belgium, and Portugal, on the other. The latter three have considerably less voting power than the UK but are among the worst compliers. Since voting power makes noncompliance more likely, it does not seem to be relevant at the shaping stage, where it should reduce the likelihood of noncompliance. Likewise, power is about resistance rather than deterrence at the taking stage. If powerful member states deterred the European Commission from opening infringement proceedings, they should face fewer infringement proceedings. My previous work corroborates these findings. It has shown that power enables member states to resist compliance against increasing pressure by EU enforcement authorities rather than deterring them (Börzel, Hofmann, and Panke 2012). Powerful states are able to sit out long and escalating infringement proceedings. Portugal and Denmark tend to cave in to the EU's compliance pressure quickly and at an early stage. Italy, France, and Germany drag their feet and frequently carry their cases to the ECJ. In some instances, they have even defied rulings of the ECJ after being convicted twice-first for violating EU law and then for not acting on the court's original judgment. Should powerful states try to use their power for deterrence, this effect is more than offset by their recalcitrance.

\section{CAPACITY}

Capacity bears similar relevance for noncompliance as voting power. Resource endowment measured by GDP per capita has the expected negative effect on noncompliance, which, however, is not significant. Greater bureaucratic efficiency brings about fewer violations of EU law. The coefficient for bureaucratic quality is negative and significant. This is in line with other studies, which find that the command of resources is less of an issue in the EU, while their efficient use does make a difference (Mbaye 2001; Hille and Knill 2006; Steunenberg 2006; Börzel et al. 2010). Compliance depends on the capacity to mobilize existing resources. This explains why France and Italy, which are among the richest member states of the EU, comply as badly as relatively poor countries like Greece and Portugal.

\section{POLITICIZATION}

The findings on politicization are mixed. The political constraints coefficient is positive but not significant. If at all, their number increases the chances of noncompliance. So does parliamentary scrutiny (see below). Similar to power, political constraints appear to matter at the taking rather than shaping stage of the compliance game. Regional authority, by contrast, is significant but does not have the expected positive sign. The contradicting results could be related to the effect the PCP model would expect regional actors to have at the shaping stage by helping member state governments to reduce compliance costs. 
My previous findings on the role of (quasi-) federal states in the implementation of EU law imply that subnational authorities differ from other political constraints, such as coalition parties or supreme courts (Börzel 2001a, 2002b). Federal states, regions, and provinces are invested with executive power, also in unitary and decentralized states where subnational authorities are administrative units (of the central state). Even if they are not formal veto players, their role in the implementation of (EU) legal acts gives them significant potential to distort at least the practical application of EU directives and regulations. In 2016, for instance, several French régions and départements reintroduced the so-called clause Molière, which requires people employed on public transport or building sites where construction is being carried out using public money to speak French. Justified as a security measure, the impositions of the use of French as the working language violates the free movement of workers as one of the four fundamental freedoms enshrined in Article 45 TFEU. Language-based restrictions on access to the labor market for EU citizens are also in noncompliance with the Posted Workers Directive of 1996, whose implementation the French regional actors had no legal power to block. ${ }^{4}$

Member states with subnational authorities that have a strong role in the implementation of EU law have developed institutionalized mechanisms to coordinate their legislative and administrative action. The conferencias sectoriales in Spain, the Italian conferenza stato-regioni, or the various committees the Belgian regions and German and Austrian Länder set up to cooperate on domestic affairs have greatly facilitated the implementation of EU law. At the same time, the vertical coordination mechanisms give subnational authorities an inlet in the shaping of EU law. Federal states even have the right to sit directly at the negotiation table when an EU law affects their exclusive competencies. Where they share authority with the central government, they have a say in the formulation of the national bargaining position. Since they can legally block the transposition of directives in the upper house of the national legislature and undermine their practical application and enforcement, their preferences are likely to be taken into account by the national governments when negotiating the directive at the EU level (Börzel 2002b; Callanan and Tatham 2014; Panara 2015). Member states may also use their regions to tie their hands, which is at least as credible as in the case of the national parliament, where governments usually control the majority (see below). Finally, regional authorities can facilitate the taking of EU law if their preferences have been accommodated at the shaping stage.

The result on the lower house of the national legislatures is in line with the expectations of the PCP model on political constraints. Parliamentary scrutiny significantly increases the chances of noncompliance. If national parliaments get a say in the transposition of directives, noncompliance becomes significantly 
more likely (Haverland, Steunenberg, and van Waarden 2011; Kaeding 2006; Mastenbroek 2003; Steunenberg and Rhinard 2010). As we will see in more detail in chapter 4, parliaments are more likely to get involved at the taking stage when directives are politicized at the EU level.

The negative and significant effect of public opposition to the EU on noncompliance corroborates the PCP expectation about governments tying their hands to Eurosceptic publics. British, Swedes, Fins, and Danes are most opposed to the EU but are the least inclined to violate EU law. In the worst compliance laggard, Italy, the EU faces little opposition; in Portugal and Greece the public is still only half as Eurosceptic as in Sweden or the UK.

\section{CONTROLS}

Benefits from intra-EU trade (Perkins and Neumayer 2007) are statistically significant. However, contrary to theoretical expectations, higher benefits correlate with more rather than less noncompliance (Mbaye 2001; Bergman 2000; Sverdrup 2004; Huelshoff, Sperling, and Hess 2005; Börzel et al. 2010). Trade with the EU may be a crude proxy for the benefits of compliance. Being an EU net recipient, however, does not show the expected sign either, nor is it significant. This is not too surprising, as the four so-called cohesion countries of the EU-15, Spain, Greece, Portugal, and Ireland, have benefited the most from EU funds compared to their membership contribution but are among the weaker compliers. ${ }^{5}$ The net contributors, by contrast, are top compliers (Denmark, Finland, Netherlands, Sweden, and UK), with the exception of Germany, which ranges in the middle. The misfit between the party preferences of the minister in charge of implementation and the EU legal act has neither the expected sign, nor is it significant. This finding is corroborated by a recent study that assessed member state compliance with regard to the correct application of directives and regulations in four policy sectors (Zhelyazkova, Kaya, and Schrama 2016). Misfit is measured at the level of individual legal acts, which are then aggregated at the member state level. Ministerial approval reflects party positions that may therefore vary across sectors rather than across member states. This could also explain why misfit has explanatory power when it comes to changes in noncompliance over time (see chapter 4).

The findings of the EU-15 model are robust when including five additional years (2013-2017), even though some of the explanatory variables had to be imputed through extrapolation from the latest available value (table A4.1). Political constraints and net recipient are still positive and now significant. As expected by the PCP model, domestic veto players appear to matter at the taking rather than the shaping stage. Receiving more money from the EU than paying in membership contributions may be an indicator of low capacity to ensure compliance rather than of the benefits of compliance. 
Power and capacity together account for a substantial part of the observed variation in member state noncompliance. Politicization needs to be brought in to fully understand why some member states comply less with EU law than others.

\section{The PCP Model at Work: Powerful, Inefficient, and Supportive of the EU}

I start with a rather simple specification of the PCP model that works with the one power and the one capacity variable that proved significant in the statistical analysis: voting power and bureaucratic quality.

\section{Voting Power and Bureaucratic Quality}

Figure 3.3 places the member states with regard to voting power and bureaucratic quality. I then compare their placement with their noncompliance behavior in relative terms.

The PCP model expects big states, such as France and Italy, whose greater share of votes in the Council makes them less sensitive to enforcement pressure and sanctioning costs, to be in more noncompliance than member states with less voting power (figure 3.3, top versus bottom). Countries with highly efficient bureaucracies, such as Denmark, Finland, the Netherlands, and the United

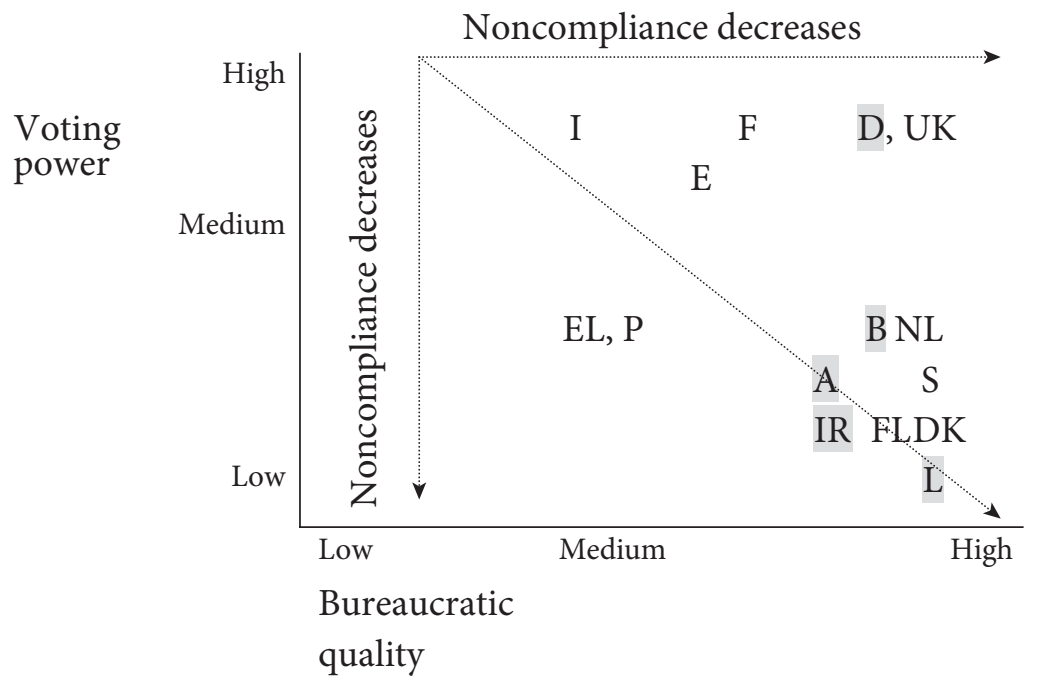

FIGURE 3.3. Power, capacity, and noncompliance in the EU-15 
Kingdom, should have a better compliance record than states with lower bureaucratic quality, such as Greece, Portugal, or Spain (figure 3.3, right versus left). The combination of limited capacity and significant power brings together the incapacity to comply and the power to be recalcitrant in the face of looming sanctions. The compliance record of member states should improve as we move from the top left to the bottom right corner of figure 3.3.

Indeed, we see considerable overlap with the actual noncompliance ranking of the EU member states (figure 3.1). Denmark and Italy mark the extremes of the infringement spectrum. Most of the other countries also perform according to where the combined effect of voting power and bureaucratic quality would place them in the noncompliance matrix (figure 3.3). Spain, Greece, and Portugal should infringe more frequently on EU law than Ireland, Luxembourg, Austria, the Netherlands, and the Nordic member states-an expectation supported by the data.

The overall predictive accuracy of power and capacity is remarkable. Combining voting power and bureaucratic quality also accounts for the noncompliance behavior of states that appear to be outliers from the perspective of enforcement and management. While the UK is as powerful as France and Italy, it complies better with EU law thanks to its higher bureaucratic efficiency. Conversely, Greece is one of the least powerful countries in the EU, but almost as bad a complier as powerful Italy. What the two member states share is the lower quality of their bureaucracies compared to Denmark and the United Kingdom.

At the same time, five member states deviate from the expectations of combined power and capacity. They are shaded in gray. Germany's level of noncompliance should be closer to the UK's, given its similar power and capacity. Austria, Belgium, Ireland, and Luxembourg, in contrast, should be in the compliance leader group with the Netherlands and the Nordic countries. They are more noncompliant than their levels of power and capacity would predict. Politicization makes sense of these deviations.

\section{Opposition to the EU and Political Constraints}

Germany has voting power and bureaucratic quality similar to those of the UK. In noncompliance, however, it is closer to Spain and France, which are equally powerful (Spain a bit less) but have less efficient bureaucracies. Germany's underperformance compared to the UK is explained by its lower propensity of domestic politicization. Despite the higher number of domestic veto players, the consistent public support for EU membership does not allow the federal government to tie its hands the way the British government was able to do with its Eurosceptic public to reduce compliance costs at the shaping stage. The English, who 
still control political majorities in the UK, have never joined the "community of Europeans" (cf. Risse 2010), which made the UK the most likely candidate for leaving the EU. The British government usually holds the majority in parliament; it faces neither federal states nor a constitutional court that could veto the incorporation of EU law into domestic structures. Despite the absence of political constraints, it could credibly tie its hand in EU negotiations to a Eurosceptic public that was easily mobilized by Europhobic media and which empowered Eurosceptic members in the House of Commons. In instances where the other member states were not willing to accommodate its policy preferences, such as the euro or Schengen, the UK opted out and ultimately left the Union for good in 2020.

Germany is politically more constrained than the UK. While low opposition to the EU mitigates the effect of political constraints on Germany's ability to shape EU law, domestic veto players undermine Germany's capacity to take EU law. The lower house (Bundestag) and the upper house (Bundesrat), as well as the powerful Federal Constitutional Court (Bundesverfassungsgericht), have resisted or at least delayed compliance with politically controversial EU laws, such as the data retention directive. ${ }^{6}$ Because of fierce political opposition in the Bundestag, Germany did not transpose the directive in time. Moreover, the Bundesverfassungsgericht declared parts of the German law transposing the directive as unconstitutional. ${ }^{7}$

Instead of pleading tied hands in order to lower compliance costs, the German government has drawn on the general public support for the EU to cut it slack getting at times costly EU laws passed that later run into opposition of powerful veto players. Germany's persistent noncompliance with the access to information directive is a case in point. The Council adopted the access to information directive by qualified majority in 1990, with Germany being the only member state that voted against. German environmental authorities at the regional and local level have fiercely opposed the directive, fearing administrative overload owing to numerous citizen requests to access documents relevant to the licensing of public and private projects, such as roads, waste dumps, or industrial plants. By contrast, the federal ministry of the environment, headed by Angela Merkel at the time, supported the new policy despite being outvoted in the Council (Börzel 2003a, $124,128)$. She went home, washed her hands of responsibility, and hoped to use the general support for the EU to overcome domestic resistance by both houses of the German parliament. Germany's power has allowed it to resist the timely and later the correct transposition of the directive for almost ten years (Börzel 2003a, 123-131). To this day, German citizens do not have the access to environmental information that EU law provides for (De Ville and Siles-Brügge 2016). ${ }^{8}$

The directive on environmental impact assessment (EIA) ${ }^{9}$ is another example of Germany resisting compliance with a costly EU law rather than seeking to 
reduce the costs at the shaping stage. The procedural approach of the directive to assess the potential impact of certain public and private projects on the environment in a cross-sectoral way has strongly contradicted the regulatory structures in Germany, whose media-specific (water, air, soil, etc.) environmental legislation lacked any comparable arrangements. The UK, in contrast, had practiced environmental impact assessments, albeit on a voluntary basis, since the 1970s. Even though the EIA directive was largely in line with its regulatory tradition, the British government raised objections against the original Commission proposal because of concerns that the EIA procedure could empower the courts vis-àvis public authorities. In over forty meetings of the Council working group on environmental affairs, it successfully negotiated a series of amendments, which, among other issues, reduced the list of projects subject to mandatory environmental impact assessment. The German government, in contrast, did not obtain any concessions that would reduce the need for substantial modifications of its environmental legislation and administrative practice. Instead, the German parliament delayed the transposition of the directive for more than two years. Then transposition was still incomplete. After the Commission had taken the issue to the ECJ twice, Germany finally enacted the required legal changes in 2001fourteen years after the directive had entered into force (Börzel 2003a, 123-131, 107-115, cf. Knill 2001).

The other four outliers lack Germany's power to resist compliance. Belgium combines high bureaucratic quality with limited voting power. It should be less noncompliant than France and Spain and be closer to the Netherlands and Sweden. What distinguishes Belgium from the two smaller states is its high degree of territorial decentralization, which constrains its autonomy. Belgium is the most decentralized member state in the EU. The federal and the regional level are each responsible for implementing EU laws that fall within their respective jurisdictions, and the regions jealously guard their competencies against any interference by the federal government (Bursens 2002, 188), as the case of the Comprehensive Economic and Trade Agreement (CETA) with Canada forcefully demonstrated. In 2016, the small Belgian region of Wallonia almost blocked the signing of the agreement, which the EU and Canada had negotiated for more than seven years. Regional veto power notwithstanding, the findings of my analysis indicate that strong regional authority leads, if it leads at all, to less noncompliance. The veto power of regional authorities may allow the Belgian government to tie its hands at the shaping stage, at least for issues of high domestic salience (see below). However, subnational authorities have become involved in the shaping of EU law to facilitate the implementation at the taking stage (Hartlapp 2009; Jensen 2007; Bursens and Geeraerts 2006; Falkner et al. 2005; Bursens 2002; Börzel 2002b, 224-226). 
What constrains Belgium politically in complying with EU law are its coalition governments. Belgium has numerous political parties, which are strictly organized along community lines - there are no national parties. Linguistic divisions between Flemish-speaking Flanders in the north and francophone Wallonia in the south have been exacerbated by the political and economic polarization between these two regions. Regionalist parties must always work together to form a federal government. In 2014 and 2019, coalition negotiations left Belgium for months without a government. With next to the highest political constraints among all member states, the country is plagued by political instability and weak central government. The literature blames Belgium's poor compliance performance on the prioritization of domestic concerns over EU obligations (Falkner, Hartlapp, and Treib 2007, 405) or "a lack of European awareness" (Bursens 2002, 189). Belgian politicians, civil servants, and public opinion, more broadly speaking, highly support the EU but simply take no interest in EU policies, making compliance with EU law "at best one goal among many" (Hartlapp 2009, 484). Similar to the situation in Germany, the low salience of EU law limits the ability of the Belgian government to reduce compliance costs at the shaping stage. At the same time, low salience reduces the chances of compliance costs to be coped with at the taking stage. Once an EU directive incurs high costs that are publicly visible and concern politically sensitive issues, Belgium's political constraints provide domestic opposition the opportunity to block or delay compliance (Falkner, Hartlapp, and Treib 2007, 409).

Ireland, Luxembourg, and Austria have still less power than Belgium to resist compliance. Compliance research on these three member states is even scarcer than on Belgium. The three countries are as small as Sweden, Finland, or Denmark but comply worse. While Austria and Luxembourg score high on bureaucratic quality, Ireland, some argue, suffers from problems similar to those of the Southern European member states, including clientelism and corruption (Siedentopf and Hauschild 1988; Laffan 1989; Coyle 1994). Together with Greece, Portugal, and Spain, Ireland once belonged to the EU's so-called cohesion countries, with a gross national income per inhabitant lower than 90 percent of the EU average. Yet Ireland experienced a period of rapid real economic growth since the first half of the 1990s, before it was hit by the banking crisis in 2008. During that time, the bureaucratic quality of the Irish administration increased significantly, reaching the levels of Germany, Denmark, and Finland (Charron, Dijkstra, and Lapuente 2010). More recent work has therefore attributed noncompliance problems to politicization rather than lacking bureaucratic quality (Laffan and O'Mahony 2008; Falkner et al. 2005). For instance, Irish farmers and landowners fiercely opposed the implementation of the so-called habitat directive, "push[ing] the issue up the political agenda and ensur[ing] that it would receive considerable 
attention in parliament, the media and from senior political figures" (Laffan and O'Mahony 2008, 184). The transposition of the directive was severely delayed and has been incomplete and incorrect. Its practical application is at best selective. The implementation of the access to environmental information directive, in contrast, has been rather smooth in the absence of domestic politicization (Bugdahn 2005). Yet, like Belgium, Ireland is a member state where domestic opposition to the EU is low. Rather than focusing on sporadic cases of highly politicized directives, the PCP model attributes Ireland's mediocre compliance record to the lack of shaping power, along with "a culture of neglect" (Falkner et al. 2005, 339). Being a poor shaper of EU law, it does not dedicate the resources necessary to ensure compliance with EU law, either.

No shaping power and low salience may also explain Luxembourg's underperformance. Luxembourg is by far the smallest member state, with the highest public support for the EU and equally high bureaucratic quality. Noncompliance therefore appears to be a question of neglect to mobilize existing resources rather than the incapacity to do so (Falkner et al. 2005, 302; Falkner, Hartlapp, and Treib 2007, 407).

Austria, finally, shares with Belgium, Luxembourg, and Ireland the capacity to implement EU law and the limited power to resist compliance pressures. Yet Austrian citizens are almost as nonsupportive of the $\mathrm{EU}$ as are the British. This has frequently resulted in domestic conflicts over EU laws, leading to serious compliance problems (Falkner et al. 2005, 271,333). The negative effect of politicization on Austria's noncompliance is amplified by the highest level of parliamentary involvement in the transposition of directives among all member states (König and Luetgert 2009). Parliamentary debates on how to transpose an EU directive into national law raise public awareness and provide an arena for domestic interests to voice their opposition to anticipated compliance costs. The question remains, however, why the Austrian government has apparently not used the high propensity of politicization to tie its hands and shape EU law to make it less costly. It seems to be the only member state in which EU opposition (and Euroscepticism more broadly) increase domestic awareness and public visibility of EU law, making domestic conflict likelier, as expected—but without increasing the government's shaping power, as a result of which we see more rather than less noncompliance.

All other Eurosceptic member states are among the top compliers. In the UK, Sweden, Finland, and Denmark, ${ }^{10} \mathrm{EU}$ opposition is significantly above EU average, and noncompliance is the lowest. Luxembourg, Belgium, and Ireland are in the opposite group, belonging to the least Eurosceptic member states, which display significantly worse noncompliance records. Given the similar bureaucratic quality and voting power of Austria, Luxembourg, Belgium, Ireland, Sweden, 
Finland, Denmark, and the Netherlands, and no systematic differences in political constraints, Euroscepticism appears to be the driver for their diverging noncompliance patterns.

The PCP model is able to account for the finding of Eurosceptic member states being less noncompliant. Legitimacy expects the opposite: lower support for the rule-setting institutions should result in more noncompliance, not less. The literature may be able to explain why Europhile Luxembourg, Belgium, and Ireland comply worse than more Eurosceptic Finland and Sweden. Compliance laggards could show greater support than compliance leaders for the EU because citizens give the EU credit for compensating the weak capacities of their state in providing public goods and services (cf. Sánchez-Cuenca 2000). This does not explain, however, why compliance leaders oppose the EU whose laws they so diligently obey. The Eurosceptic member states have sufficient capacity to comply with EU law. Rather than being a side-product of capacity, the negative correlation between EU opposition and noncompliance suggests an indirect effect of the former on the latter, which works through the power to shape EU policies as proposed by the PCP model. Member state governments with a Eurosceptic home constituency are in a better position to bargain for EU laws that entail lower compliance costs. Instead of a permissive consensus, they face a "constraining dissensus" (Hooghe and Marks 2009), which limits the range of EU policy outcomes acceptable back home. Whether governments use the possibility to tie their hands to a Eurosceptic public is a different matter, which may explain why Eurosceptic Austria complies worse than Finland or Sweden. Likewise, tying hands is not the only bargaining strategy of small states to shape EU policies (Panke 2010a; Börzel 2002a). EU-supportive Netherlands is very effective in writing policy drafts for the European Commission and brokering compromises among the member states, often punching above its weight (Liefferink and Andersen 1998; Kronsell 2002). It might therefore comply equally well with EU law as more Eurosceptic Finland and Sweden. Finally, member state governments that have to deal with Eurosceptic publics among their electorates are less likely to cut slack in achieving policies at the EU level that would not get adopted domestically.

In sum, the outliers of the combination of voting power and bureaucratic quality are best captured by politicization. Eurosceptic publics enhance the ability of small states to shape EU law according to their preferences, reducing compliance costs. This explains why Europhile Belgium, Ireland, and Luxembourg comply worse than more Eurosceptic Sweden or Finland, although they have similar capacities to comply with EU law and equally limited power to resist compliance costs. The more effective shaping of EU law can also account for the different compliance behavior of two member states with equal voting power and bureaucratic quality. Germany and the UK both have the capacity to take 
compliance costs, as well as the power to resist them. The UK was a much more effective shaper of EU law than Germany (Börzel 2002a), even though it is less politically constrained. Rather than veto players, the higher risk of politicization gave the UK greater bargaining leverage. Costly and publicly visible EU laws are more likely to mobilize domestic opposition. The UK faced lower compliance costs and had less cause to be recalcitrant. At the same time, Germany has more opportunities for cutting slack, which, however, may backfire if the implementation of an EU legal acts becomes politicized and mobilizes various institutional veto players.

Politicization can make noncompliance both more and less likely. The paradox is resolved by an interlinked but differential effect of politicization on the two stages of EU policy making. At the taking stage, politicization increases the likelihood that governments prefer noncompliance, particularly if they face powerful domestic veto players in the implementation process. At the shaping stage, member state governments facing greater risks of domestic opposition in implementation have the power to shape EU legal acts so that they incur lower compliance costs.

\section{Traveling East}

While the analysis so far has been confined to the fifteen long-standing member states, the PCP model also accounts for the rather good performance of the ten CEE countries that joined in 2004 and 2007. A comparison of the annual reasoned opinions of new member states relative to the mean of old member states during the first ten years of membership confirms once again that the CEE newcomers outperform most of the old member states (figure 3.2; cf. Börzel and Sedelmeier 2017; Börzel and Buzogány 2019). The newcomers transpose EU directives even before the deadline. Moreover, efficient transposition does not come at the price of weak practical implementation (Zhelyazkova, Kaya, and Schrama 2017). While the new member states lose their edge further down the implementation chain, they do not lag behind the older member states when it comes to practical application. The new member states do not generally constitute a "world of dead letters," except for the area of social policy that Falkner and colleagues examined (Falkner, Treib, and Holzleitner 2008).

At the same time, there is significant variation. Poland and, to a lesser extent, the Czech Republic are on their way to joining the compliance laggards. The other new member states are firmly in the leaders' camp. Top CEE laggard Poland resembles Spain, having considerable voting power, while its bureaucratic quality is weak. The Czech Republic has less voting power and accordingly is not as noncompliant as Poland. The eastern compliance leaders, in contrast, appear to 
perform much better than the combination of power and capacity would expect (figure 3.4, shaded in gray). Their power is small, but their capacity is as low or, in the case of Romania and Bulgaria, even lower than Greece's. Nevertheless, their noncompliance rates match those of the Netherlands, Finland, or Sweden (figure 1.3 in chapter 1). The reason for the counterintuitive performance of most of the eastern new member states lies in the specific capacity that they built for implementing EU law during the accession process.

According to the so-called acquis conditionality, the candidate countries had to incorporate large parts of the existing EU legislation into their domestic laws and put administrative procedures in place that would ensure effective application and enforcement. This was accomplished through administrative coordination mechanisms established during the accession process, which centralized the adoption of the acquis in the hands of the core executive and gave parliaments little voice. Moreover, the accession process helped build the bureaucratic quality of candidate countries to get EU laws on the books, which was a priority of the Commission (Hille and Knill 2006; Dimitrova and Toshkov 2009; Steunenberg and Dimitrova 2007; Sedelmeier 2008; Toshkov 2008; Zubek 2005; Zubek 2011; Börzel and Sedelmeier 2017). The EU provided candidate countries with substantive financial and technical assistance. Moreover, the inefficiency of postcommunist bureaucracies led the executives to centralize the policy process for

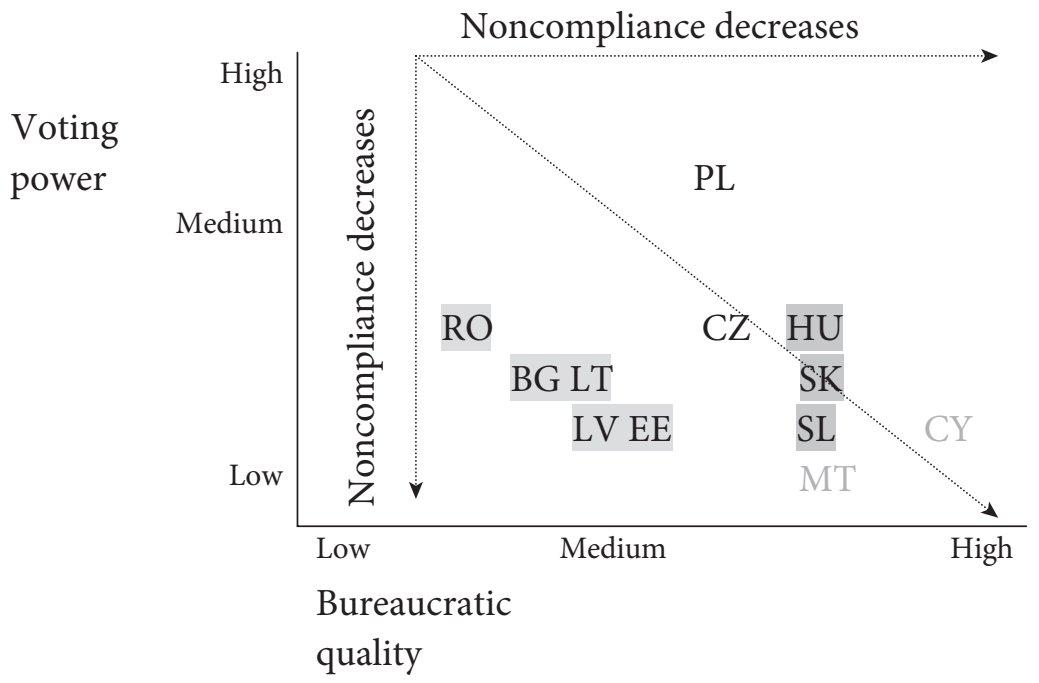

FIGURE 3.4. Power, capacity, and noncompliance in the new member states $(\mathrm{EU}-10+2) *$

* Malta and Cyprus are not part of the Central and Eastern European newcomers. 
the implementation of EU law and to use fast-track procedures to bypass parliament and shield themselves against other political constraints (Sadurski 2006). The new centralized procedures allowed the tracking of EU-related legislative commitments, to monitor progress and to review the quality of transposition (Zubek 2011). They entailed "sophisticated EU co-ordination mechanisms which often included levels of co-ordination and political attention unseen in the 'older' member states" (Dimitrova and Toshkov 2009, 2; cf. Dimitrova and Toshkov 2007). These "islands of excellence" (Goetz 2001) are as efficient in coordinating the taking of EU policies as the more general administrative coordination mechanisms in old member states with overall high bureaucratic quality (Verheijen 2007).

The use of pre-accession conditionality and pre-accession assistance toward the new members to improve their bureaucratic quality explains why they perform better than the Southern Europeans despite the generally low capacity in these countries. In other words, the capacity of the newcomers to comply with EU law is higher than their generally low bureaucratic quality suggests (Goetz 2001; Verheijen 2007, 25-27; Sedelmeier 2008, 20-21). The establishment of narrower and specific capacities for the implementation of EU law is not captured by general capacity indicators. At the same time, similar bureaucratic quality and voting power explain why the performance of most of the CEE is closer to the compliance leaders of the EU-15, and why Poland's performance as the only middle power among the newcomers deviates from the overall good compliance record of the others, closing in with Spain, with its similar voting power and bureaucratic quality (figure 1.3 in chapter 1 ).

Finally, pre-accession conditionality may also explain why support for European integration appears to be negatively related to noncompliance. Unlike in the EU-15, Europhile new members comply better, not worse, with EU law. First, pre-accession conditionality made them exclusive takers of the vast majority of EU law. When they joined, the newcomers had to have on the books the entire body of EU law that was in force at the time of their accession. Afterward, they continued to be takers, given the EU's tendency to amended existing legislation rather than adopt new laws (see chapter 4). Second, greater public support for EU membership propelled pro-EU governments into power, which were willing and empowered to pool resources and centralize procedures as to ensure the swift implementation of EU law to prove themselves as trustworthy members (Perkins and Neumayer 2007; Toshkov 2008; Sedelmeier 2008; Börzel and Sedelmeier 2017). The eagerness to improve bureaucratic quality in areas related to EU law shows above all in transposition, where centralized mechanisms are particularly effective in ensuring that legal implementation of EU law is timely. The effect begins to wear off in practical implementation, which is more decentralized. Yet 
public support for the EU makes politicization of compliance costs less likely. This explains why the new member states lose their cutting edge in practical implementation, without, however, performing worse than the old member states (Zhelyazkova, Kaya, and Schrama 2016, 2017).

After accession, many pro-EU governments were swept out of power and replaced by right-wing populist forces with Eurosceptic leaders, such as Viktor Orbán in Hungary and the Kaszyński brothers in Poland (Taggart and Szczerbiak 2004; Houghton 2014). Yet public support for the EU has remained stable, even in Hungary and Poland. This may suggest that people did not necessarily vote for right-wing populist parties primarily because they are Eurosceptic.

Evaluating the relevance of the PCP model for the enlarged EU is still tricky. The period of membership is rather short, particularly for Romania and Bulgaria, which only joined in 2007. They are therefore excluded. Moreover, a number of independent variables lack data, including EU intra-trade, ministerial approval, and parliamentary scrutiny, which had to be dropped. The results for the remaining variables, however, are still interesting.

The principal components of the PCP model are robust (table 3.2). Voting power, bureaucratic quality, and opposition to the EU show the same effect on noncompliance as in the EU-15. Political constraints have the same positive effect, which is significant now. Regional authority changes the sign but is not significant. The results for net recipient and GDP per capita also differ between the EU-25 and the EU-15. Both are now statistically significant. GDP per capita turns positive, while net recipient has no substantial impact. These changes may be explained by the homogeneity of the EU-15 with regard to the three variables. Once we control for old versus new members by introducing a highly significant EU-15 dummy, the results of the EU-15 and EU-25 model converge. Net recipient and GDP per capita lose significance, and the latter turns negative. Regional authority returns to be negative but remains insignificant. Only four of the ten CEE newcomers have substantial levels of regional authority, of which two, the Czech Republic and Poland, comply below average. These two member states are the only ones with democratically elected regional governments (Loughlin, Hendriks, and Lidström 2012). Moreover, the level of involvement of subnational authorities in EU policy making still has to catch up with the old member states (Panara 2015; Baun and Marek 2008; Bruszt 2008; Scherpereel 2007). Political constraints, finally, has a positive effect on noncompliance, which is highly significant. This is unlikely to be related to the accession of ten new member states, which do not systematically differ from the EU-15 by exhibiting stronger political constraints. I suspect it is a spurious correlation. For lack of data, I could not include intra-EU trade-which is highly significant in the EU-15 model —in the EU-25 model. If I take intra-EU trade out of the EU-15 model, 
TABLE 3.2 Power, capacity, and politicization (EU-25, 1979-2012)

\begin{tabular}{|c|c|c|}
\hline & (1) & (2) \\
\hline \multicolumn{3}{|l|}{ Power } \\
\hline Voting power (SSI) & $\begin{array}{l}\mathbf{0 . 0 6 1 3 * * *} \\
(0.00628)\end{array}$ & $\begin{array}{l}\mathbf{0 . 0 5 6 0 * * *} \\
(0.00609)\end{array}$ \\
\hline \multicolumn{3}{|l|}{ Capacity } \\
\hline GDP per capita & $\begin{array}{l}\mathbf{0 . 0 1 0 5 * * *} \\
(0.00201)\end{array}$ & $\begin{array}{c}-0.000448 \\
(0.00268)\end{array}$ \\
\hline Bureaucratic quality (ICRG) & $\begin{array}{l}-\mathbf{0 . 0 3 4 7 * * *} \\
(0.00461)\end{array}$ & $\begin{array}{l}-\mathbf{0 . 0 2 9 6 * * *} \\
(0.00440)\end{array}$ \\
\hline \multicolumn{3}{|l|}{ Politicization } \\
\hline Political constraints & $\begin{array}{l}\mathbf{0 . 0 0 4 4 4 * *} \\
(0.00177)\end{array}$ & $\begin{array}{l}\mathbf{0 . 0 0 5 4 1}^{* * *} \\
(0.00172)\end{array}$ \\
\hline Regional authority & $\begin{array}{c}0.00239 \\
(0.00219)\end{array}$ & $\begin{array}{c}-0.00325 \\
(0.00222)\end{array}$ \\
\hline EU opposition & $\begin{array}{l}-\mathbf{0 . 0 1 7 2 * * *} \\
(0.00290)\end{array}$ & $\begin{array}{c}-\mathbf{0 . 0 2 1 4} * * * \\
(0.00283)\end{array}$ \\
\hline \multicolumn{3}{|l|}{ Controls } \\
\hline Net recipient & $\begin{array}{l}\mathbf{0 . 0 0 0 1 9 2 * *} \\
(7.48 \mathrm{e}-05)\end{array}$ & $\begin{array}{l}0.0000871 \\
(7.43 e-05)\end{array}$ \\
\hline EU-15 & & $\begin{array}{l}\mathbf{0 . 6 4 5 * * *} \\
(0.101)\end{array}$ \\
\hline Constant & $\begin{array}{l}2.324 * * * \\
(0.185)\end{array}$ & $\begin{array}{l}2.170 * * * \\
(0.183)\end{array}$ \\
\hline Observations & 520 & 520 \\
\hline Number of years & 34 & 34 \\
\hline
\end{tabular}

Standard errors in parentheses

$* * * \mathrm{p}<0.01, * * \mathrm{p}<0.05, * \mathrm{p}<0.1$

political constraints turn significant. The observation that the effect of political constraints turns strongly significant only when controlling for intra-EU trade may suggest that political constraints pick up some of the variation left unexplained by not including intra-EU trade. The two variables correlate significantly (table A2.1).

In sum, the core variables of the PCP model show robust results. Voting power, bureaucratic quality, and EU opposition have the expected effect on noncompliance in both the EU-15 and the enlarged EU-25. They also stand the robustness check with updated models, which include five more years (2017) but have to rely on imputed values for certain variables for the lack of data (tables A4.1 and A4.2). The positive effect of political constraints appears to depend on whether we control for intra-EU trade. In the most recent model for the EU-27, political constraints are highly significant, even though intra-EU trade could not be included (table A4.2). While I can only speculate at this point, the PCP model would expect domestic veto players to gain in importance owing to the growing politicization of the EU, particularly in the EU- 15 . 
Noncompliance research has focused on explaining why states do not comply with legal acts they have agreed on in the first place. The findings of this chapter confirm that power and capacity matter but need to be combined with politicization to account for why some states comply less than others. Moreover, we have to disentangle specific variants of the three principal components of the PCP model whose relevance differs depending on the stage of the compliance game. Thanks to their voting power in the Council, member states are able to resist compliance costs at the taking stage rather than to reduce costs at the shaping stage. At the shaping stage, in turn, politicization matters, as Euroscepticism allows governments to tie their hands and negotiate for EU laws closer to their policy preferences. Veto players, in contrast, impair the ability of governments to take EU law and its costs, making noncompliance more likely. Capacity, finally, matters for both stages. However, it is efficiency in mobilizing existing resources, and not resource endowment, that increases the ability of member states to shape and take EU law.

By bringing politicization into the equation, the PCP model explains why countries with rather high bureaucratic quality and similar voting power vary in their noncompliance with EU law, depending on how much their publics support or oppose the EU. Belgian, Irish, or Luxembourgian citizens, who are generally supportive of the EU, tend to take little or at best selective interest in EU law. Low salience results in noncompliance, because existing capacity is not used in the implementation of EU law. Eurosceptic publics, in contrast, are likely to be more aware of and mobilize against the $\mathrm{EU}$ and its policies, giving their governments greater leverage in negotiating less costly laws. Politicization as driven by Euroscepticism allows us to account for the consistent but counterintuitive finding that higher EU support increases the chances of member state noncompliance.

Overall, Euroscepticism has not increased in the member states over the past forty-five years. But politicization is not only driven by Eurosceptic publics. With the expansion of the EU's political authority, the media has become more receptive of EU affairs, and Eurosceptic parties have used the various crises the EU has faced since 2005 to mobilize EU opposition in national elections and referenda (De Wilde and Zürn 2012; Risse 2015b; De Wilde, Leupold, and Schmidtke 2016; Hutter, Grande, and Kriesi 2016). Interestingly though, the growing awareness of, mobilization around, and polarization of the EU and its policies in the member states have neither undermined public support for the EU as such nor resulted in more noncompliance with EU law, as we will see in the next chapter. The exceptions are EU budgetary rules and asylum and migration laws. EU budgetary rules are not subject to infringement proceedings but rely on their own monitoring and enforcement regime in the euro zone. So do violations of the fundamental values of the EU codified in treaty articles, which so far have been confined to 
Hungary and Poland. Asylum and migration, however, are part of JAIN, which subsequently moved from intergovernmental coordination under the third pillar of the Maastricht Treaty to supranational decision making applying to most areas of the Internal Market (the former first pillar; cf. Börzel 2005, 2010). As we will see in chapter 5, JAIN is the policy sector where noncompliance is most pronounced. 